\title{
Teaching the English Color Idioms
}

\author{
God’spower Tamaraukuro Prezi
}

Niger Delta University, Wilberforce Island, Nigeria

\begin{abstract}
This paper takes a look at the color idioms in English and their meanings. We note that the color idioms are idioms that deal with colors or include at least a color within the idiom. Most of the important color idioms are presented here in one place in alphabetical order and are easy and ready to use. We have deliberately avoided clichés and slang. We take a look at some of the ways in which and through which we can teach the English color idioms to students in the classroom. We conclude by saying that it behoves us as language teachers in higher institutions of learning to teach the English color idioms as they not only constitute part of the lexis of the natural speech of native English speakers, but they are also a vital tool for teaching collocations connected with color idioms. And, of course, color idioms make one's language more colorful.
\end{abstract}

Keywords: idioms, color idioms, color-only idioms, color-plus idioms, clichés, slang, collocations

\section{Introduction}

An "idiom" is a word or phrase which means something different from the literal meaning of the individual word(s) that make up the expression. Laflin (1993, p. iii) said that an idiom is a phrase which means something different from the meanings of the separate words that are a part of it. Another definition of an idiom is that it is "the assigning of a new meaning to a group of words which already have their own meaning" (Makkai, as cited in Curry, 1998).

"Colors" are often used in idiomatic expressions in English. Some of the most common idioms come from colors. "Color idioms", therefore, are idioms that deal with colors or include at least a color within the idiom. Most Britons and Americans use color idioms, especially when they discuss informally with one another, and, consequently, color idioms form a very important part of British and American English. They give life and richness to the English language. Idioms are formed from existing words, by combining them in a new sense, thus bringing forth new expressions which in turn expand the scope and vocabulary of the English language.

English idioms are often informal in nature, i.e., colloquial. Some English idioms are now overused or commonplace expressions and are often called "clichés", while other idioms are "slang”. They may also take the form of proverbs. Idioms may belong to the nominal, verbal, adjectival, or adverbial word classes.

For the student of English as a second or foreign language, learning to use color idioms and idiomatic expressions correctly is an important aspect of the mastery of British, American, and indeed, International English. They need to use these expressions or phrases to make their language more colorful.

God'spower Tamaraukuro Prezi, lecturer, Department of English and Literary Studies, Faculty of Arts, Niger Delta University. 
The color idioms presented in this paper are only a small selection from the numerous color idioms that exist in English, because they occur regularly in natural native English speech and/or in reading materials used by English language learners worldwide.

Now, what is new in this paper, which you cannot find elsewhere, is that the color idioms are presented here in alphabetical order or almost, and are easy to use. Furthermore, you would find all the important color idioms in one place, that is, in this paper, ready to use in the teaching-learning process.

\section{The Colors}

The list of well-known colors in English are: beige, black, blue, brown, green, grey, orange, pink, purple, red, white, and yellow.

Many colors are associated with feelings or moods in English. However, as can be seen from this paper, only the colors black, blue, brown, green, grey, pink, red, white, and yellow are mostly associated with idioms in English.

The English color idioms can be divided into two convenient headings: the color-only idioms and the color-plus idioms.

Firstly, we shall take a look at the color-only idioms. These are idioms that comprise only the color word (see Example 1):

Example (1) black: despair.

black and white: simple, clear and understandable; clearly distinct or different; either good or bad, either one way or the other way but not in between; in writing, officially.

black and blue: bruised.

blue: sad; cold.

green: to be inexperienced or immature; envy.

purple: rage.

red: furious; angry.

white: fear.

yellow: cowardly.

Next, we take a look at the color-plus idioms. These are idioms that comprise the color word together with some other words. That is, the color word occurs in an expression to form the idiom (see Example 2):

Example (2) black eye: a bruise near one's eye which makes it appear black; a bad reputation. in the black: successful or profitable; not showing a financial loss.

put down in black and white: to write the details of a contract or something on paper.

blue funk: British English: scared; American English: (very) depressed.

a blue-eyed boy: a boy/young man who has been singled out for special favours by someone in authority; a boy/young man who is liked and admired by someone in authority.

out of the blue (to appear/happen) [also a bolt from the blue]: to happen very suddenly and unexpectedly; without any warning, by surprise.

to look/feel blue: to look/feel depressed or discontented. 
blue in the face: exhausted from anger, strain, or other great effort; weakened, tired after trying many times.

get/have the blues: to feel or become sad or depressed.

talk until you are blue in the face: to talk until you are exhausted.

to blue-pencil something: to censor something.

a grey area: something that is not clearly defined and may have a broad or more than one answer, and is therefore difficult to deal with.

green: to be inexperienced or immature.

green around the gills: looking sick.

green with envy (to be): to be very jealous of another person's property; to be full of envy; wishing very much that you had what someone else has.

green-fingered/green thumb: to be good at keeping plants healthy and making them grow. A talent for gardening, the ability to make things grow.

in the pink: in very good health.

pink slip: a termination notice from a job.

tickled pink: to be very happy, pleased or delighted by someone or something.

to see red: (to become) very angry.

in the red: to be in debt; to be unprofitable; showing a financial loss.

out of the red: out of debt.

like waving a red flag in front of a bull: what you are doing will definitely make someone angry or upset.

red-eye: an airplane flight that leaves late at night and arrives early in the morning; an unwanted photographic effect in which a person's iris appears to be red.

white lie: a harmless or small lie told to be polite or to avoid hurting someone's feelings; small, insignificant lie.

as white as a sheet: very pale; frightened.

white elephant: a burdensome or useless possession, creating more trouble than it is worth; a rare, expensive possession that is a financial burden to maintain and has no useful purpose.

yellow (be): be a coward; to be cowardly.

the yellow press: popular and sensationalist newspapers; newspapers that deliberately include sensational news items to attract readers.

Finally, we shall put all these color idioms, nicely and neatly, in a tabular form as given in Table 1.

The lecturer explains to the students that the faces of white native speakers of English actually appear to change color as follows: (1) The faces of white native speakers of English actually appear to go black when they are in despair; (2) Their faces appear to be blue when they feel cold; (3) White bóxers faces and body appear to look black and blue when they are bruised and beaten; (4) Their faces appear to look green when they are envious; (5) Also, the faces of white native speakers of English actually appear to go purple when they are in rage; (6) Their faces turn red when they are furious or angry; (7) White native speakers faces appear to be very white when they are afraid; and (8) Their faces appear to be yellow when they are cowardly. 
Table 1

Idioms With Their Meanings and Examples

\begin{tabular}{|c|c|c|c|}
\hline No. & Idiom & Meaning & Examples in sentences \\
\hline 1 & black and blue & $\begin{array}{l}\text { bruised and beaten; } \\
\text { (to hit or beat someone until they } \\
\text { are) covered with bruises; } \\
\text { injured in a fight either physical or } \\
\text { verbal. }\end{array}$ & $\begin{array}{l}\text { (1) We found the security man black and blue near the hospital gate. } \\
\text { (2) Peter the boxer lost the fight. He was beaten black and blue. } \\
\text { (3) Ebiowei came out of the meeting with his manager black and } \\
\text { blue since he had made so many mistakes preparing the report } \\
\text { without consultation. }\end{array}$ \\
\hline 2 & $\begin{array}{l}\text { not as black as he/she/it } \\
\text { is painted }\end{array}$ & not as bad as people say he/she/it is. & $\begin{array}{l}\text { Augustina is not as black as she is painted. She found Stephen's } \\
\text { money and returned it! }\end{array}$ \\
\hline 3 & in the black (be) & $\begin{array}{l}\text { successful or profitable; } \\
\text { to have money in your bank } \\
\text { account; } \\
\text { not showing a financial loss. }\end{array}$ & $\begin{array}{l}\text { (1) UBA has managed to stay in the black for the financial year } \\
\text { ending December } 31,2012 \text {. } \\
\text { (2) Ganrere is very careful with how she spends her money and } \\
\text { so she's always in the black. } \\
\text { (3) Ejiro is always in the black and does not have to worry about } \\
\text { money. }\end{array}$ \\
\hline 4 & black and white & $\begin{array}{l}\text { straight forward, very clear; } \\
\text { simple and understandable; } \\
\text { clearly distinct or different; } \\
\text { either good or bad; } \\
\text { either one way or the other way but } \\
\text { not in between; } \\
\text { in print or in writing, officially. }\end{array}$ & $\begin{array}{l}\text { The rules we give our children are black and white. They mus } \\
\text { not answer any knock on the door or the door bell. }\end{array}$ \\
\hline 5 & in black and white & $\begin{array}{l}\text { to write the details of a contract or } \\
\text { something on paper. }\end{array}$ & $\begin{array}{l}\text { Moses never thought the opposition party would put his } \\
\text { scandalous secret in black and white on the front page of the } \\
\text { Punch newspaper for that matter. }\end{array}$ \\
\hline 6 & blue & cold. & Her hands were blue with cold. \\
\hline 7 & $\begin{array}{l}\text { blue-eyed } \\
\text { (somebody's) }\end{array}$ & $\begin{array}{l}\text { a boy/young man who has been } \\
\text { singled out and given special } \\
\text { favourable treatment by someone in } \\
\text { authority; } \\
\text { a boy/young man who is liked and } \\
\text { admired by someone in authority. }\end{array}$ & $\begin{array}{l}\text { Peter is the Ekeremor Local Government Area chairman's } \\
\text { blue-eyed boy. }\end{array}$ \\
\hline 8 & blue in the face & $\begin{array}{l}\text { to do something or talk until one is } \\
\text { exhausted from anger, strain, or } \\
\text { other great effort; } \\
\text { weakened, tired after trying to do } \\
\text { something as hard and as many } \\
\text { times as you possibly can but } \\
\text { without success. }\end{array}$ & $\begin{array}{l}\text { Lawrence, you can argue until you are blue in the face, but you } \\
\text { will not change my mind on this matter. }\end{array}$ \\
\hline 9 & $\begin{array}{l}\text { browned off (with } \\
\text { somebody) }\end{array}$ & bored, unhappy, and/or annoyed. & $\begin{array}{l}\text { (1) By now the passengers on Titanic II were getting browned off } \\
\text { with the delay in departure due to ice warnings. } \\
\text { (2) Tony Blair browned-off with Gordon Brown over affairs of State. }\end{array}$ \\
\hline 10 & $\begin{array}{l}\text { feel blue (look blue)/to } \\
\text { have the blues }\end{array}$ & to become sad or depressed. & $\begin{array}{l}\text { (1) Rachael seems very unhappy these days. I wonder why she is } \\
\text { feeling blue. } \\
\text { (2) Last month Sandra lost her job and her boyfriend broke up } \\
\text { with her, so she is really feeling blue. } \\
\text { (3) Let us try to cheer up the Super Eagles. They have been } \\
\text { feeling blue since they did not go to the last African Cup of } \\
\text { Nations in Gabon and Equatorial Guinea. } \\
\text { (4) Hannah was feeling blue because no one paid her any } \\
\text { attention at the Governor's birthday party. } \\
\text { (5) During winter, I feel blue. I do not want to do anything. I just } \\
\text { want to stay in bed. } \\
\text { (6) I always have the blues during the winter time because I can } \\
\text { hardly go out, and I love outdoor activities. } \\
\text { (7) A lot of people have the blues on Monday, because they do } \\
\text { not want to go back to work after a long and enjoyable weekend. }\end{array}$ \\
\hline
\end{tabular}


(Table 1 continued)

\begin{tabular}{|c|c|c|c|}
\hline No. & Idiom & Meaning & Examples in sentences \\
\hline 11 & once in a blue moon & very rarely. & We only go out for dinner once in a blue moon. \\
\hline 12 & out of the blue & unexpectedly; suddenly. & $\begin{array}{l}\text { (1) I was walking across the road when a car appeared out of the } \\
\text { blue. } \\
\text { (2) The news of John's death came out of the blue. No one was } \\
\text { expecting it because he was still very young. } \\
\text { (3) I got the news out of the blue that Jane was getting married! } \\
\text { (4) I got a phone call out of the blue from Lawrence and George } \\
\text { Abanwan last month. }\end{array}$ \\
\hline 13 & green & to be inexperienced or immature. & Joe is still green on the job at the gym. \\
\hline 14 & green around the gills & looking sick. & $\begin{array}{l}\text { Having been on the boat all day, Simon Peter was a little green } \\
\text { around the gills. }\end{array}$ \\
\hline 15 & $\begin{array}{l}\text { green thumb/ } \\
\text { green-fingered }\end{array}$ & $\begin{array}{l}\text { a talent for gardening, i.e., the } \\
\text { ability to make plants grow } \\
\text { successfully and keep them healthy. }\end{array}$ & $\begin{array}{l}\text { (1) Ebiere really has a green thumb. Everything she plants in her } \\
\text { garden grows so well. } \\
\text { (2) You must have quite a green thumb. Your flowers are always } \\
\text { so beautiful and healthy-looking. }\end{array}$ \\
\hline 16 & green with envy (be) & $\begin{array}{l}\text { very jealous of another person's } \\
\text { property; } \\
\text { wishing very much that you had } \\
\text { what someone else has. }\end{array}$ & $\begin{array}{l}\text { (1) Joe is green with envy over Samson's new office. } \\
\text { (2) I was green with envy when I learned that Tam won first prize } \\
\text { in the football lottery-he got a free trip to Old Trafford! } \\
\text { (3) Ebiere felt green with envy when her sister won the beauty } \\
\text { and singing contest in which she also took part. } \\
\text { (4) If you say that someone is green with envy, you mean that the } \\
\text { person is really very envious. }\end{array}$ \\
\hline 17 & grey area & $\begin{array}{l}\text { something without a clear rule or } \\
\text { answer; } \\
\text { something that is not clearly defined } \\
\text { and may have a broad answer or } \\
\text { more than one answer, and is } \\
\text { therefore difficult to deal with. }\end{array}$ & $\begin{array}{l}\text { Writing personal email in the office is a grey area that needs to } \\
\text { be discussed at the next Administrative Board meeting. }\end{array}$ \\
\hline 18 & in the pink & in very good health. & My grandmother is in the pink. \\
\hline 19 & tickled pink & \begin{tabular}{|l|} 
very much pleased and appreciative \\
or entertained.
\end{tabular} & $\begin{array}{l}\text { (1) My mother was tickled pink when my father brought a brand } \\
\text { new car and roses home for her. } \\
\text { (2) When Gloria arrived home on Christmas eve and saw that } \\
\text { her husband had decorated the whole house, she was tickled } \\
\text { pink. }\end{array}$ \\
\hline 20 & see red & to be very angry. & $\begin{array}{l}\text { (1) My sister saw red when the thief grabbed her purse. } \\
\text { (2) Roseline had such a huge fight with her mother-in-law that } \\
\text { she saw red. }\end{array}$ \\
\hline 21 & red eye & $\begin{array}{l}\text { an airplane flight that takes off after } \\
\text { midnight. }\end{array}$ & $\begin{array}{l}\text { I caught the red eye so I could see the sunrise over the Chilean } \\
\text { mountains. }\end{array}$ \\
\hline 22 & red tape & $\begin{array}{l}\text { paying attention to the wording and } \\
\text { details of rules and regulations, } \\
\text { especially by government workers; } \\
\text { official or bureaucratic tasks. }\end{array}$ & $\begin{array}{l}\text { (1) There is still some red tape to deal with in terms of the } \\
\text { Frederic's inheritance from his grandfather's estate. } \\
\text { (2) My boss is all about due process; creativity is crushed in } \\
\text { favour of red tape. }\end{array}$ \\
\hline 23 & red in tooth and claw & $\begin{array}{l}\text { involving opposition or competition } \\
\text { that is violent and without pity. }\end{array}$ & $\begin{array}{l}\text { The presidential election bid of the PDP and CPC candidates is } \\
\text { one that is red in tooth and claw. }\end{array}$ \\
\hline 24 & in the red & in debt; losing money. & $\begin{array}{l}\text { (1) When we were in the red we almost sold our house. } \\
\text { (2) I spent too much money from my salary this month and don't } \\
\text { have enough money in the bank to pay for my expenses and feed } \\
\text { myself. I am in the red. } \\
\text { (3) Preye enjoys shopping so much that she is always in the red } \\
\text { by the end of each month. } \\
\text { (4) Since Lala lost his job, his bank account has been in the } \\
\text { red. }\end{array}$ \\
\hline 25 & a red rag to a bull & $\begin{array}{l}\text { something that is likely to, or will } \\
\text { definitely, make somebody very } \\
\text { angry or upset. }\end{array}$ & $\begin{array}{l}\text { When a guy snatches his friend's girlfriend, it's like showing } a \\
\text { red rag to a bull. }\end{array}$ \\
\hline
\end{tabular}


(Table 1 continued)

\begin{tabular}{|c|c|c|c|}
\hline No. & Idiom & Meaning & Examples in sentences \\
\hline 26 & white lie (little) & $\begin{array}{l}\text { a harmless small, minor or } \\
\text { insignificant lie, especially one that } \\
\text { you tell to avoid hurting somebody } \\
\text { or to be polite; } \\
\text { a fib. }\end{array}$ & $\begin{array}{l}\text { (1) We told Nene that her banga soup was delicious, which was } \\
\text { actually a white lie, because it was horrible. } \\
\text { (2) Doubara told her parents a white-lie that she had been at the } \\
\text { library, but she had also gone to watch the movies. } \\
\text { (3) John told the policeman a little white lie that he had been } \\
\text { driving for months, but he did not say he was doing so illegally. } \\
\text { (4) I did not feel like going to the party with John, but I didn't } \\
\text { want to hurt his feelings, so I told } a \text { white lie and said I was busy. } \\
\text { (5) Sandra's baby is not really pretty, but I told her that her baby } \\
\text { was sweet and cute. I told her } a \text { white lie. } \\
\text { (6) I told Stella } a \text { white lie. I did not want to attend her birthday } \\
\text { party so I said I was busy. }\end{array}$ \\
\hline 27 & $\begin{array}{|lr|}\text { yellow/be } & \text { yellow/have } \\
\text { a r yellow } \\
\text { streak/yellow-bellied }\end{array}$ & \begin{tabular}{|l|} 
cowardly; \\
be a coward; \\
to be cowardly; \\
extremely timid, coward, not brave.
\end{tabular} & $\begin{array}{l}\text { (1) Peter is not brave enough to stand up and fight with Klishko. } \\
\text { He is yellow. } \\
\text { (2) The outlaws knew they could ride into town and take over, } \\
\text { because the sheriff was too yellow to fight. }\end{array}$ \\
\hline 28 & $\begin{array}{l}\text { the yellow press/yellow } \\
\text { journalism }\end{array}$ & $\begin{array}{l}\text { popular and sensationalist } \\
\text { newspapers; newspapers that } \\
\text { deliberately include sensational } \\
\text { news items to attract readers; } \\
\text { journalism that is exaggerated or } \\
\text { unnecessarily sensational. }\end{array}$ & $\begin{array}{l}\text { (1) Headlines that are sensational and untrue are examples of } \\
\text { yellow journalism. } \\
\text { (2) Some newspaper reporters engage themselves in yellow } \\
\text { journalism to boost the sale of their newspapers. }\end{array}$ \\
\hline
\end{tabular}

The following are sample exercises on English color idioms for students to do (as classwork or assignment).

(1) Fill in the gaps in the following sentences with the appropriate color from the list given.

black/blue/green/purple/red/white/yellow

(a) When John saw my gold wristwatch he was... with envy. (green)

(b) Since losing her job Sandra has been in a mood of... despair. (black)

(c) When Peter realized the danger he was in, he went... with fear. (white)

(d) The principal gets furious with latecomers to the Assembly Hall: he really sees... (red)

(e) When he saw the mess he had created, he went... with rage. (purple)

(f) I knew Samson didn't have the guts to tell her he loved her: he’s really... (yellow)

(g) It's freezing here in Siberia, in December. I'm... with cold. (blue)

(2) Fill in the gaps in the following sentences with the appropriate color idiom from the list given.

tickled pink/black and blue/have the blues/blue moon/golden opportunity/out of the blue/the red eye/green light/silver spoon/true colours

(h) Mr Agih says he was... to be (mis)taken for a French man. (tickled pink)

(i) The boxer was... after the 10th round of the bout in the tournament. (black and blue)

(j) When you... you feel sad or depressed. (have the blues)

(k) When something happens... it is unexpected. (out of the blue)

(l) I caught... means I took a flight after midnight. (the red eye)

(m) Tonye saw... (red) $=$ Tonye got very angry.

(n) Ebitimi was... with envy. (green) = Ebitimi was very envious.

(o) What's the matter? You look as... as a sheet. (white) = You look very pale. 
(p) I was tickled... when I heard the news of my promotion. (pink) $=$ I was really very happy when I heard the news of my promotion.

(q) The news of my promotion came out of the... (blue) = The news of my promotion came as a surprise.

(r) I'm really... ed off about it. (brown) = I'm really fed up, annoyed about it.

(s) Suddenly Timiyo... ed out. (blacked) = Suddenly, Timiyo fainted.

(t) The Agricultural Science student has... fingers. (green) $=$ The Agricultural Science student can grow plants successfully.

(u) It only happens once in a... moon. (blue) = It only happens very occasionally.

(v) Going to South Africa 2012 is a... opportunity which we mustn’t miss. (golden) = a very good (rare) opportunity.

(w) I was in a... funk. (blue) $=$ I was very scared .

(x) Silva was born with a... spoon in his mouth. (silver) = Silva was born into a wealthy family.

(3) Each example below has an idiom with a color word. Guess the meaning of each idiom from the context and try to match each idiom (numbered 1-10) with its meaning (a-j).

(4) Let the students answer certain Yes/No Questions involving color idioms.

\section{Teaching Procedure, Points, and Hints}

Let the students know that color idioms are idioms from colors. Color idiom lessons can be brief activities that you can use as fillers at the beginning or end of the lesson. This activity can be done as a quick revision test. Firstly, you could ask them to read the sentences and discuss with their partner what color they could expect to fill the blank spaces, and the colors it associates with emotions. Or you may group the idioms that are derived from one color in a bunch and teach them to the students as a full lesson.

In teaching the English color idioms, we need: first of all, to know what idioms are; secondly, what the well-known colors are; thirdly, to define what a color idiom is; fourthly, to provide illustrative sentences for each of the color idioms, with paraphrases, synonymous expressions, and functional activities; fifthly, to use illustrative sentences together with the paraphrases to provide an application of the color idiom in context dialogues, in a short text or in a story; and sixthly, to give students an opportunity to use the idioms in context as well as with some degree of realism in real-life situations.

Curry (1998) gave us the following five teaching hints for idioms in general, which we can also apply in teaching the color idioms: (1) give definitions and illustrative sentences orally, followed by the paraphrase of the illustrative sentence. Ask students to repeat the illustrative sentences; (2) give paraphrase again orally. Ask students to give the illustrative sentence; (3) give synonymous expressions and their definitions. Substitute the synonymous expressions in the appropriate illustrative sentence and have students repeat the new sentences; (4) give students an opportunity to compose original sentences using the functional activity for oral practice; and (5) assign selected students to prepare and present in class short dialogues (2-4) lines using the idiom and/or synonymous expressions.

In addition to the above, we may: (1) Give the students the following form of sample exercise to do in class or as assignment. Each example below has an idiom with a color word. Guess the meaning of each idiom from the context and try to match each idiom (1-10) with its meaning (a-j); and (2) Let the students answer certain Yes/No Questions involving color idioms. 


\section{Conclusions}

It is indeed important for us as teachers of English and linguistics in institutions of higher learning to teach the English color idioms, in addition to the other idiomatic expressions, as they not only constitute part of the lexis (i.e., the vocabulary) of the natural speech of native speakers of English especially in informal dialogues, but they also are a vital tool for teaching collocations as a by-product of the whole exercise of teaching the English color idioms.

We notice also, for instance that while the very recently introduced color idiom, blue funk means scared in British English, in American English it means (very) depressed.

Furthermore, we observe that many colors including gold(en) and silver are associated with feelings or moods in English. However, the colors that are mostly associated with idioms in English are black, blue, brown, green, grey, pink, red, white, and yellow.

Some of the most common idiomatic expressions in British and American English are color idioms, i.e., idioms that include at least a color. Most Britons and Americans use color idioms, especially when they discuss informally with one another, and, consequently, color idioms form a very important part of British and American English. Color idioms give life and richness to the English language.

\section{References}

BBC Learning English. (2009). Colour idioms: The teacher. Retrieved from http://www.youtube.com/Teachers Brieger, N., \& Jackson, A. (1992). Advanced international English: Student book. Hertfordshire: Prentice Hall. Chalmers, R. (2010). Linguaspectrum. Retrieved from http://www.bbc.co.uk.../learning english/.../...

Collins Cobuild, Advanced Learner's English Dictionary. (4th ed.). (2003). Glasgow: Harper Collins Publishers. Curry, D. (1998). Illustrated American idioms. Washington, D.C.: United States Information Agency.

English Club. (2012). Colour idioms. Retrieved from http://www.englishclub.com/vocabulary

English Vocabulary. (2012). Interesting idioms with colours. Retrieved from http://www.abaenglish.com/.../english...english... Hornby, A. S. (2001). Oxford advanced learner's English dictionary (6th ed.). Oxford: Oxford University Press. Jennifer. (2012). ESL video lessons colour idioms. Retrieved from http://www.teachya.com/

Laflin, S. V. (1993). Something to crow about: A concise collection of American English idioms for everyday use. Washington, D.C.: United States Information Agency.

Learn4Good Ltd.. (2012). List of colour idioms in English. Retrieved from http://www.learn4good 4good.com/...Idioms/id-c.htm Muthusamy, R. (2011). Colour idioms in English language and their meaning. Retrieved from http://guides.wikinut.com/Col... Swift, S. (n.d.). An ELT notebook: Colour idioms. Retrieved from http://eltnotebook.blogspot.com/.../colour-idioms 